\title{
SURGICAL DEBRIDEMENT AND THE LEGAL RESPONSIBILITIES OF NURSES
}

\author{
Isabel Cristina Ramos Vieira Santos ${ }^{1}$, Regina Célia de Oliveira², Mailton Alves da Silva
}

\footnotetext{
${ }^{1}$ Ph.D. in Sciences. Adjunct Professor at Faculdade de Enfermagem Nossa Senhora das Graças (FENSG) University of Pernambuco (UPE). Pernambuco, Brazil. E-mail: tutornad@yahoo.com.br

${ }^{2}$ Ph.D. in Nursing. Adjunct Professor at FENSG/UFPE. Pernambuco, Brazil. E-mail: reginac_oliveira@terra.com.br

${ }^{3}$ RN. Stomatherapist. Pernambuco, Brazil. E-mail: maylton@hotmail.com
}

\begin{abstract}
This study aimed at analyzing the legal responsibilities of the professional pertinent to surgical debridement. It consists of a documental study with categorical data analysis. Data were collected through the websites of the Regional Nursing Councils. The material was submitted to the content analysis technique. Results revealed three categories: document subject and text theme, definition and classification of debridement a diversity of concepts and conclusion of documents concerning the nurse's legal competence in the performance of surgical debridement. The results of this categorical analysis showed the need for a single federal organizational policy to standardize the practice of conservative surgical debridement by nurses, considering: the standardization of terms, so as to avoid different interpretations and attitudes; and limits of execution, considering indications and contraindications to the cited method, as well as prerequisites for the necessary qualification.
\end{abstract}

DESCRIPTORS: Nursing. Wound healing. Debridement.

\section{DESBRIDAMENTO CIRÚRGICO E A COMPETÊNCIA LEGAL DO ENFERMEIRO}

RESUMO: O estudo objetivou analisar os dispositivos legais da profissão, pertinentes à temática desbridamento cirúrgico. Trata-se de uma pesquisa documental com análise categorial dos dados. Os dados foram coletados através dos sites dos Conselhos Regionais de Enfermagem. O material foi submetido à técnica de análise de conteúdo. Como resultados revelaram-se três categorias: assunto do documento e a temática do texto, definição e classificação de desbridamento, uma diversidade de conceitos, e da conclusão dos documentos à competência legal do enfermeiro para realização do desbridamento cirúrgico. Os resultados da análise categorial mostraram a necessidade de uma política única, a partir do órgão federal, que normatize a prática do desbridamento cirúrgico conservador por enfermeiros, considerando: a padronização de termos, de modo a evitar diversas interpretações e atitudes, limites de execução, considerando inclusive indicações e contraindicações para o referido método além dos requisitos quanto à capacitação necessária.

DESCRITORES: Enfermagem. Cicatrização de feridas. Desbridamento.

\section{DESBRIDAMIENTO QUIRÚRGICO Y COMPETENCIA DE LOS ENFERMEROS}

RESUMEN: El estudio tuvo como objetivo analizar los dispositivos legales de la profesión, relacionados con el desbridamiento quirúrgico tema. Esta es una investigación documental con un análisis categórico de datos. Los datos fueron recolectados a través de la web del Consejo Regional de Enfermería. El material fue sometido a la técnica de análisis de contenido. Los resultados revelaron tres categorías: el tema del documento y la temática del texto, definición y clasificación de desbridamiento, una amplia gama de conceptos y la conclusión de documentos a la competencia legal de los enfermeros para llevar a cabo el desbridamiento quirúrgico. Los resultados de la análisis categórico mostró la necesidad de una política única de la agencia federal que regula la práctica de desbridamiento quirúrgico conservador para los enfermeros teniendo en cuenta: la normalización de los términos, para evitar diferentes interpretaciones y actitudes, límites de ejecución, teniendo en cuenta las indicaciones y contraindicaciones de la este método más allá de los requisitos para la formación necesaria.

DESCRIPTORES: Enfermería. Cicatrización de heridas. Desbridamiento. 


\section{INTRODUCTION}

The term 'to debride' comes from the French débrider, which means "clearing the way to". It was probably employed for the first time as a medical term by surgeons hundreds of years ago in war zones, once they recognized that contaminated wounds involving soft tissue had a better chance of healing if the necrotic tissue was removed surgically. ${ }^{1-2}$

The removal of necrotic tissue through debridement is beneficial for several reasons. Debridement removes dead, devitalized or contaminated tissue, as well as any foreign body in the wound, helping to reduce the number of microorganisms, toxins and other substances that inhibit healing. ${ }^{2}$

In developed countries such as England, Canada and the United States there are regulations outlining the professional responsible for the practice of debridement, and they point out the cost savings of public resources when surgical debridement is performed in the community by a qualified nurse. ${ }^{1,3}$

In Brazil, surgical debridement performed by nurses remains a controversial theme, raising questions among professionals of nursing and other disciplines who traditionally perform the procedure in the country concerning the technical and legal requirements for its execution.

Hence, mainly in basic health care, nurses still face a high quantity of patients with chronic lesions who could heal satisfactorily and in a reduced amount of time if the nurses were provided with legal support for the execution of this procedure. These are patients whose healing is delayed and even complicated, often in detriment to the patient's quality of life ${ }^{4}$, due to difficulties in accessing medical care that is already overloaded with other responsibilities inherent in this care level.

The execution of surgical debridement by a technically and legally capable nurse would, therefore, add effectively to the health team, assuring quality public health care.

In face of this presupposition, the present study aimed to analyze the legal mandates issued by the Regional Councils in Brazil pertinent to surgical debridement and compare them to the existing references.

\section{METHODS}

This study consists of a documental research with a descriptive approach. Study sources included the websites of the Regional Nursing Councils (Conselhos Regionais de Enfermagem - CORENs) and the website of the Federal Nursing Council (Conselho Federal de Enfermagem - COFEN), as well as texts regarding the subject in order to subsidize the study theoretically. The navigation of the websites took place between February and April of 2011.

The first stage of the study consisted of accessing the websites of COREN, performed through its main page, and then searching for legislation regarding debridement on the website of each regional council.

The second stage involved organization of the material, processing the readings according to the criteria of Bardin's content analysis, ${ }^{5}$ and based on breaking the text down into units; that is, discovering the different nuclei of meaning constituting communication. After this general and broad reading, detailed reading was initiated, aimed at regrouping them into classes or categories. Hence, this third stage consisted of a process of coding, interpretation and inferences regarding the information contained in the documents, revealing their manifested content.

The fourth and last stage constituted the superimposing of information from other relevant national and international texts, so as to compare legal and complementary texts to the analysis of the theme.

The search was performed on the main page of the Brazilian Federal Agency for Support and Evaluation of Graduate Education (CAPES) electronic database. The selection of descriptors used in the search was determined through the verification of descriptors in BIREME health sciences. In the searches, the following descriptors in Portuguese and English were considered: debridement, surgical debridement, conservative surgical debridement, instrumental debridement. Besides these, the terms "Brazil" and "Brazilian" were also used to locate manuscripts containing results of national studies.

\section{DOCUMENTARY DATA ANALYSIS AND PRESENTATION}

In Brazil, 27 regional councils, located in every state, fall under the auspices of the Fed- 
eral Nursing Council. The purpose of the system formed by these institutions - the COFEN/ COREN system - is to standardize the activities of the nursing profession, managing the quality of the services provided and ensuring compliance with the laws governing the profession.

The search for documentation regarding the regulation of the practice of debridement by nurses resulted in five documents issued by five different states, with four being in the form of a report $^{6-9}$ and one being a resolution. ${ }^{10}$ Through the search for the meaning of words and their effect under the law, it is understood that a report is a "grounded opinion regarding a certain subject, issued by an expert"11:1565, whereas a resolution may be understood as a "discussion to study or solve a matter, [...] or making a decision" ${ }^{11: 1565}$ Thus, it is perceived that, in terms of law, a resolution carries greater relevance than a report. ${ }^{12}$

According to the location of the COREN that issued the document (Chart 1), it is observed that almost all Brazilian regions have made declarations regarding the subject of debridement, except for the north region. This indicates the concern of nurses around the country in regards to the treatment of wounds, in which the practice of debridement is included as an activity of their profession.

Regarding the year of issuance of the document, it is observed that the standardization of nursing actions in the treatment of cutaneous lesions is recent, with Minas Gerais being the first state to issue a legal document in the form of a resolution on the matter. ${ }^{10}$

It is worth pointing out that the treatment of cutaneous lesions in Brazil has only recently become a target of focused research. Despite the fact that there is no mention in the scientific literature regarding the precise time, a study developed by researchers from Rio de Janeiro states that the subject of wound care has only been addressed in Brazil since the $90^{\prime}$ s. $^{13}$

Considering this, a fact that illustrates the concern of professionals and researchers from Minas Gerais is the development of an updated course on dressing techniques, taught by a multidisciplinary team from the continuing education network in Belo Horizonte in 1996 (perhaps the first course of this nature in Brazil). The content of this course includes surgical debridement and discusses subjects such as criteria, technique, limitations and evaluation of results. ${ }^{14}$

As may be observed in chart 1 , four years after this event the state COREN issued a resolution concerning "competency of nursing professionals in the prevention and treatment of cutaneous lesions". 10:1

The change in paradigm of the ideal wound healing environment from dry to moist, with emphasis on the need for evaluation of the wound to determine the appropriate cleansing actions, debridement and wound dressings, was introduced in this course (and from there, hypothetically disseminated throughout the country) and may have contributed to a greater reflection on the part of the nurses who took over wound care responsibilities formally performed only by physicians. This reflection is expressed legally and temporally through other issued documents, which, as observed in chart 1 , specifically addressed debridement.

\section{Chart 1 - Organization of the official documents analyzed}

\begin{tabular}{|c|c|c|l|}
\hline COREN & Doc & No./Year & \multicolumn{1}{c|}{ Subject } \\
\hline COREN-MG & $\mathrm{R}$ & $65 / 2000$ & $\begin{array}{l}\text { "Competency of nursing professionals in the prevention and treatment of cutaneous } \\
\text { lesions". } 0: 1\end{array}$ \\
\hline COREN-SC & $\mathrm{r}$ & $010 / 2004$ & "Mechanical debridement of wounds". $6: 1$ \\
\hline COREN-DF & $\mathrm{r}$ & $004 / 2007$ & $\begin{array}{l}\text { "Opportunity for the nurse to indicate the necessity for, and/or execute, surgical de- } \\
\text { bridement of necrotic and devitalized tissue and obtain samples of tissue from le- } \\
\text { sions for culture and microbial sensitivity tests".7:1 }\end{array}$ \\
\hline COREN-SP & $\mathrm{r}$ & $013 / 2009$ & "Execution of debridement by the nurse". $8: 1$ \\
\hline COREN-PE & $\mathrm{r}$ & $016 / 2010$ & "Debridement of wounds by nursing professionals".9:1 \\
\hline
\end{tabular}

$\mathrm{R}=$ resolution; $\mathrm{r}=$ report.

Considering the study purposes, three categories were outlined. Each document category is described as follows, presenting documentary excerpts and contextualized analysis. 


\section{Category 1 - Document subject and text theme}

Although all five documents address the theme of debridement (Chart 1), it is important to observe that there is a great variability in the "subject"; that is, what is expressed in the document title.

In the resolution issued by the council of Minas Gerais (COREN-MG), "debridement" does not appear in the title, although it is mentioned in the document content. This resolution addresses, broadly, the competency of nursing professionals in the prevention and treatment of cutaneous wounds. Therefore, it addresses the entire nursing profession, and not specifically the nursing class.

In Brazil, the nursing profession is comprised of two classes or categories, nurses and nursing technicians; both play an important role in the care of cutaneous lesions, not only at the preventive level but also in healing, with different levels of complexity of their actions.

Therefore, according to the Minas Gerais document, it is the nurse's duty to "execute debridement, whenever necessary". 10:1

Among the five documents existing in Brazil up until now, this is the only one that clearly presents the responsibility of the two classes of nursing professionals regarding the treatment of wounds, in which the practice of debridement is included.

The document issued by the council of Santa Catarina (COREN-SC) specifies in its title (subject) the specific modality of "mechanical debridement" ${ }^{\prime \prime}: 1$

The report from the COREN of the Federal District (COREN-DF) is the only one that specifically indicates the performance of surgical debridement in its title. ${ }^{7}$ The latter two documents, from the councils of São Paulo and Pernambuco (COREN-SP and COREN-PE), address only the performance of debridement with differences between them regarding the referred professionals; that is, the report issued by COREN-SP ${ }^{8}$ emphasizes on the execution of the procedure by nurses, whereas the report issued by COREN-PE ${ }^{9}$ refers to nursing professionals.

Considering that the practice of debridement consists of four methods according to the mechanism of action, including surgical/instrumental, mechanical, autolytic and chemical, and that the mentioned titles did not specify any of those methods, it may be considered that their content will address all of them and, if so, the surgical or instrumental method may not be considered to be a competency of all nursing professionals, as this method presupposes a broader technical knowledge.

\section{Category 2 - Definition and classification of debridement: a diversity of concepts}

Three of the analyzed documents ${ }^{8-10}$ include a definition of debridement in their text bodies, as demonstrated in chart 2 .

As observed, all three documents define debridement as the removal of devitalized tissue and foreign material. The resolution issued by COREN-MG, ${ }^{10}$ different from the other two, associates debridement with a traumatic lesion.

Necrotic tissue is the dead tissue that usually results from an inadequate local blood supply. It contains dead cells and fragments of these cells. The color of this tissue changes as it becomes more dehydrated. Eventually, a dark, dry, thickened and fibrous structure is formed. This tissue may be seen in a great variety of wounds, including burns and all types of chronic wounds. In contrast, slough is a yellow fibrous tissue that consists of fibrin, suppurative and proteinaceous material. ${ }^{3}$ Slough may be found on the surface of wounds that have been cleansed previously and may be associated with bacterial activity. The accumulation of necrotic tissue or slough in a chronic wound has high clinical relevance, since its occurrence promotes bacterial colonization and prevents the wound from healing, making its removal imperative., ${ }^{2,15}$

Hence, it is not possible to state that only traumatic (acute) wounds should be debrided, as any type of wound containing necrotic tissue requires some form of debridement.

\section{Chart 2 - Definitions of debridement in the official documents analyzed}

\begin{tabular}{|c|l|}
\hline COREN & \multicolumn{1}{c|}{ Definition of debridement } \\
\hline COREN-MG & $\begin{array}{l}\text { "Removal of devitalized tissue or foreign material from a traumatic lesion, including adjacent } \\
\text { tissue which may or may not be infected, until the wound is surrounded completely by healthy } \\
\text { tissue". }{ }^{9: 4}\end{array}$ \\
\hline COREN-SP & "[...] the act of removing devitalized tissue and/or foreign material from the wound ".7:1 \\
\hline COREN-PE & "[...] removal of necrotic and foreign tissue from a wound". ${ }^{8: 1}$ \\
\hline
\end{tabular}


Regarding the classification of debridement, from the analysis of the subjects (titles) of the documents, the classifications expressed in the analyzed documents are presented as follows (Chart 3).

The report issued by COREN-DF ${ }^{7}$ was the only document, which did not include the methods of debridement, perhaps because the subject of the cited legal document had already expressed clearly that the text addressed surgical debridement specifically.

Only COREN-SC 6 and COREN-PE ${ }^{9}$ presented the definitions of all four debridement methods, although there are differences among the terms used. For instance, the COREN-SC ${ }^{6}$ document utilized the terms "instrumental or surgical debridement", whereas the COREN-PE 9 document discussed "surgical debridement", similar to the document issued by COREN-SP. ${ }^{8}$

The COREN-SC ${ }^{6}$ document uses the term "enzymatic debridement", whereas the COREN$\mathrm{PE}^{9}$ document refers to the same procedure as chemical or enzymatic debridement".

The documents issued by the councils of Minas Gerais, ${ }^{10}$ Santa Catarina ${ }^{6}$ and Pernambuco ${ }^{9}$ include a definition of autolytic debridement. Although the COREN-SP ${ }^{8}$ report has a reference to this method, its definition is not provided in the text.

Moreover, the resolution issued by CORENMG presents "debridement with a cutting instrument"10:4 as a category of the mechanical method, differing from the definitions given by the other councils.

Mechanical debridement consists of the application of mechanical force directly on the necrotic tissue. ${ }^{16}$ In this definition, the concept of force is related to changes in the quality and depth of movement, which differs from the definition used to describe surgical debridement as using a cutting instrument as an agent of action; the use of force in this case is secondary and is conditional on the efficacy of the mentioned instrument.

\section{Chart 3 - Classification of debridement according to the official documents analyzed}

\begin{tabular}{|c|c|c|c|c|}
\hline \multirow{2}{*}{ COREN } & \multicolumn{4}{|c|}{ Methods } \\
\hline & Surgical & Mechanical & Chemical & Autolytic \\
\hline $\begin{array}{l}\text { COREN- } \\
\text { MG }^{10}\end{array}$ & - & $\begin{array}{l}\text { Friction: "to rub a gauze } \\
\text { or sponge soaked with } \\
\text { saline solution on the le- } \\
\text { sion in one direction." 10:4 } \\
\text { With a cutting instrument: } \\
\text { "to remove the necrotic } \\
\text { tissue using cutting in- } \\
\text { struments (blades and/or } \\
\text { scissors)". 10:4 }\end{array}$ & $\begin{array}{l}\text { Chemical: "through the } \\
\text { action of proteolytic en- } \\
\text { zymes, which remove the } \\
\text { devitalized tissue through } \\
\text { the degradation of col- } \\
\text { lagen".10:6 }\end{array}$ & $\begin{array}{l}\text { Autolytic: "through autolysis; that } \\
\text { is, the autodegradation of the } \\
\text { necrotic tissue under the action } \\
\text { of lysosome enzymes, released } \\
\text { by macrophages". }{ }^{10: 6}\end{array}$ \\
\hline $\begin{array}{l}\text { COREN- } \\
\text { SC }^{6}\end{array}$ & $\begin{array}{l}\text { Instrumental or surgi- } \\
\text { cal debridement "con- } \\
\text { sists of the removal of } \\
\text { necrosis using a scal- } \\
\text { pel, scissors or any } \\
\text { other cutting instru- } \\
\text { ment". } 6: 1\end{array}$ & $\begin{array}{l}\text { Mechanical debridement } \\
\text { "consists of the removal } \\
\text { of necrotic tissue with the } \\
\text { application of mechanical } \\
\text { force". } 6: 1\end{array}$ & $\begin{array}{l}\text { Enzymatic debridement is } \\
\text { "obtained through the topi- } \\
\text { cal application of debrid- } \\
\text { ing enzymes directly on } \\
\text { the necrotic tissue". } 6: 1\end{array}$ & $\begin{array}{l}\text { Autolytic debridement "involves } \\
\text { the use of synthetic dressings or } \\
\text { coverage on the wounds to allow } \\
\text { the autodestruction of the devi- } \\
\text { talized tissue with the help of the } \\
\text { enzymes that are normally pres- } \\
\text { ent in the wound fluids". }{ }^{6: 1}\end{array}$ \\
\hline $\begin{array}{l}\text { COREN- } \\
\text { SP }^{8}\end{array}$ & $\begin{array}{l}\text { Surgical debridement } \\
\text { "consists of the remov- } \\
\text { al of necrotic tissue } \\
\text { through a surgical pro- } \\
\text { cedure, with the use of } \\
\text { scissors or scalpels". } 8: 2\end{array}$ & $\begin{array}{l}\text { Mechanical debridement: } \\
\text { "performed with the use } \\
\text { of jets of saline solution } \\
\text { at } 2 \text { to } 10 \text { pressure per } \\
\text { square meter, gauze or } \\
\text { any other material that } \\
\text { mechanically removes } \\
\text { the devitalized tissue". }\end{array}$ & $\begin{array}{l}\text { Chemical debridement: } \\
\text { "performed through the } \\
\text { use of dressings or sub- } \\
\text { stances with autolytic and } \\
\text { chemical properties, which } \\
\text { keep the environment } \\
\text { moist and appropriate for } \\
\text { the debridement of the } \\
\text { Iseion". }\end{array}$ & - \\
\hline $\begin{array}{c}\text { COREN- } \\
\text { PE }^{9}\end{array}$ & $\begin{array}{l}\text { Surgical debridement } \\
\text { "consists of the re- } \\
\text { moval of necrosis with } \\
\text { a scalpel, scissors or } \\
\text { other cutting instru- } \\
\text { ment".9:1 }\end{array}$ & $\begin{array}{l}\text { Mechanical debridement } \\
\text { "consists of the removal } \\
\text { of necrotic tissue with } \\
\text { application of mechanical } \\
\text { force". } 9: 1\end{array}$ & $\begin{array}{l}\text { Chemical or enzymatic } \\
\text { debridement: "obtained } \\
\text { through the topical appli- } \\
\text { cation of exogenous sub- } \\
\text { stances (enzymes) directly } \\
\text { on the necrotic tissue." 9:1 } \\
\end{array}$ & $\begin{array}{l}\text { Autolytic debridement "involves } \\
\text { the use of synthetic coverage on } \\
\text { the wounds to allow a moist and } \\
\text { vascular environment that favors } \\
\text { the autodestruction of the devi- } \\
\text { talized tissue". }{ }^{: 1}\end{array}$ \\
\hline
\end{tabular}


The current definition for surgical debridement is the removal of necrotic tissue or foreign material from the wound to expose healthy tissue using a sterile scalpel, scissors or both. ${ }^{1}$ It is observed, thus, that the definition relies on the tissue to be removed and the material or instruments used to effect the removal.

In Brazil, nursing has created new terms, ${ }^{6,10,17}$ perhaps due to a concern in distinguishing it from the procedure that has been traditionally executed by the physician, or because it is taking into consideration the environment used for its execution. However, if we use logic, there is no difference between the term "surgical debridement" and the others used in nursing, such as: instrumental debridement ${ }^{6}$ or with cutting instrument. ${ }^{10}$

In terms of what was observed in the analyzed literature, the literature disseminated in Brazil also uses different terms for surgical debridement. One of them ${ }^{17}$ describes this procedure as "instrumental", subclassifying it as "conservative" (referring to the method selectivity) and "surgical", relating it to the volume of the material removed. Other authors ${ }^{16}$ use the term "surgical debridement", applying this term when it is performed in a surgical center or at the "bedside", finding support on instructional technical instrument for health teams of the Brazilian Ministry of Health. ${ }^{18}$

Regarding scientific studies published in nursing journals, the search of CAPES' main page did not yield any Brazilian studies that discuss the practice of surgical debridement by nurses. In the international literature, the terms surgical debridement, ${ }^{20,22}$ serial surgical debridement, ${ }^{19}$ conservative surgical debridement ${ }^{1,21}$ and instrumental debridement ${ }^{3}$ are used synonymously with surgical debridement.

The discussion regarding the use of such terms is useful and necessary when attempting to determine the most appropriate term to use. Standardization of the term will prevent confusion regarding which procedure is being referred to.

By way of synthesis of this discussion regarding the procedure terminology and semantics, the use of the term "instrumental" does not differ from the term "surgical", since the analysis of the word instrumental indicates: instrumental - "serving as a means of instrument, related to instruments"11:1168, and instrument - "object... serving as mechanical agent in the execution of any task: surgical instruments". ${ }^{11: 1168}$
Therefore, the location of the procedure, whether it is at the bedside, in the hospital or at home, does not change the fact that aseptic technique must be used in addition to the surgical instrument, although with less strictness at home than when performed at a surgical center.

The difference between the terms used by nursing applies, thus, only to the serial manner in which this procedure may be performed. Using semantics once again, it is observed that conserve means "to protect from loss or harm, preserve", 11:562 and that is the great advantage of using this term in conjunction with "surgical debridement" and performance by nurses, considering that despite the lack of statistical data in Brazil, wounds affect the population at large, regardless of gender, age or socioeconomic class, thus constituting a serious public health problem which increases public expenses and decreases the quality of life of the population. In light of this, qualified nurses have much to contribute, which will be discussed in the next category.

\section{Category 3 - Conclusion of the documents regarding the legal right of the nurse to perform surgical debridement}

The COREN-MG ${ }^{10}$ resolution states that it is within the nurse's scope to perform debridement; however, it does not specify the method, giving an opportunity for several interpretations (Chart 4).

In the first item of the conclusion, the report issued by COREN-SC ${ }^{6}$ clearly does not authorize the nurse to execute surgical debridement. In the second item of the conclusion it regulates the execution of debridement using the slice technique, or the removal of thin layers of tissue utilizing a cutting instrument. ${ }^{16,23}$ Thus, clarity is lost. The conclusion of the report issued by COREN-PE ${ }^{9}$ also lacks objectivity in terms of the regulation of the practice of surgical debridement only by nurses.

The report issued by COREN-DF ${ }^{7}$ is clearer on this subject, since the title specifies that this document exclusively addresses this practice and establishes the limit of tissue to be debrided by the nurse (not to include the subcutaneous tissue). The conclusion of the report of COREN-SP ${ }^{8}$ is also very clear and, similar to the document issued by COREN-DF, ${ }^{7}$ it also establishes the limit to be debrided to avoid the subcutaneous tissue. 
It is important to observe that, with the exception of the documents of COREN-SC ${ }^{6}$ and COREN-SP, ${ }^{8}$ no other conclusions of the analyzed documents conditions the practice of surgical debridement on the need for some level of qualification.

Several studies ${ }^{1-3,20-24}$ have noted the therapeutic and economical impact of this debridement method on the treatment of wounds. Its practice by nurses may potentially prevent hospital admissions or decrease the period of hospitalization, in addition to reducing the time of nursing care, infection and costs associated with the treatment of wounds, also promoting healing and improvement in the quality of life of the patients.

Around the world, the diversity of the care provided to patients with wounds has resulted in the creation of international associations and societies with the purpose to define and unify common terms, as well as to establish comprehensive education for the structuring of universal parameters in this field.

While the debridement of wounds, in general, is defined within the nursing scope, surgical debridement is a specialized level of wound care, demanding educational preparation, practical supervision and a regulatory process of competency evaluation so that the nurse may develop this skill with safety and efficiency, in addition to being capable of handling complications. ${ }^{1,2021}$
Although it is believed that conservative surgical debridement is selective, there may be damage to viable tissue, including possible bleeding. ${ }^{2}$

Competence means having the ability or authority to do what is required and accepting responsibility for the work executed. Many authors highlight potential legal problems for the execution of debridement and emphasize the importance of competency, not only based on practical ability involved in the removal of devitalized tissue, but also on the anatomic knowledge necessary in regards to the adjacent structures. ${ }^{1-3,20-22}$

In the United Kingdom, surgical debridement is performed far more frequently by nurses, particularly in community care. ${ }^{3}$ In the United States, registered nurses may perform surgical debridement after being certified through education, which is recognized with supervised clinical practice. ${ }^{3}$ Similarly in Canada, in the provinces of Alberta and Quebec and in the Yukon Territory, registered nurses are authorized to perform conservative surgical debridement. ${ }^{1}$

Therefore, it is understood that the knowledge provided by graduate courses are not enough for this practice and a resolution is needed, whether it comes from associations or legal organizations, regarding the minimum prerequisites necessary for the accreditation of nurses for the execution of this procedure.

\section{Chart 4 - Resolutions/conclusions of the analyzed documents according to COREN}

\begin{tabular}{|c|c|}
\hline COREN & Resolution/Conclusion \\
\hline COREN-MG & $\begin{array}{l}\text { "Art. } 1^{\text {st }}-\text { It is within the professional nurse's scope to: [...] execute debridement, whenever neces- } \\
\text { sary". } .^{10: 1}\end{array}$ \\
\hline COR & $\begin{array}{l}\text { "01. Except for surgical debridement, the nurse may execute mechanical, enzymatic and autolytic de- } \\
\text { bridement, as long as provided with the respective technical-scientific knowledge and abilities required } \\
\text { for the procedure. } 02 \text {. The properly qualified nurse may execute debridement using the slice technique, } \\
\text { depending on the protocol established by the multidisciplinary team". } \text {. }^{2}\end{array}$ \\
\hline $\mathrm{COF}$ & $\begin{array}{l}\text { "[...] the nurse may indicate the need for and/or execute debridement of necrotic and devitalized tissue, } \\
\text { as well as remove samples of tissue from lesions for culture and microbial sensitivity test, at the subcu- } \\
\text { taneous tissue level, when the need for surgical intervention is not recognized". }{ }^{7: 2}\end{array}$ \\
\hline COREN-SP & $\begin{array}{l}\text { "[...] the nurse may take over the procedure of lesion debridement... whether it is mechanical, enzy- } \\
\text { matic, autolytic or conservative instrumental when there is no need for surgical intervention. It is high- } \\
\text { lighted that in case of debridement with the use of cutting instruments, the removal of devitalized tissue } \\
\text { excluding the subcutaneous level may be performed, according to the institution protocol". }{ }^{: 4}\end{array}$ \\
\hline COREN-PE & $\begin{array}{l}\text { "[...] it is within the nurse's scope to execute activities of higher technical complexity, which is addressed } \\
\text { in this report. It is important to highlight that the nurse must be fully aware of the practiced acts or those } \\
\text { to be taken over, respecting his/her limits of competence and responsibility". } 9: 2\end{array}$ \\
\hline
\end{tabular}




\section{FINAL CONSIDERATIONS}

The clinical domain that includes the management of risks, auditing and practice based on evidence aims at helping nurses improve the quality of care and protect care standards, assuring that professionals have the right qualifications, abilities and competencies to provide the necessary care to patients.

Qualifying specialist nurses in the care of patients with wounds, certified by recognized courses and available to the market, responsible for the execution of conservative surgical debridement, will certainly facilitate cost effective treatments provided to patients with wounds.

Collectively, through professional organizations, and also individually, nurses must be responsible for their technical standards. Before performing debridement they must make sure they have the necessary technical skills, and that this ability is included in the scope of professional regulations and that there is a policy to support them.

The results of this study showed the need for a single federal organizational policy to regulate the practice of conservative surgical debridement by nurses, considering the standardization of the term based on semantics and on scientific logic so as to avoid diverse interpretations and attitudes, establishing limits of execution, decreasing risks, and considering indications and contraindications for the cited method, as well as prerequisites for the necessary qualification.

\section{REFERENCES}

1. Harris RJ. The nursing practice of conservative sharp wound debridement: promotion, education and proficiency. Wound Care. 2009 Jan-Mar; 7(1):22-30.

2. Wolcott RD, Kennedy J, Dowd S. Regular debridement is the main tool for maintaining a healthy wound bed in most chronic wounds. J Wound Care. 2009 Feb; 18(2):54-6.

3. Bates-Jensen BM, Apeles NCR. Management of necrotic tissue. In: Sussman C, Bates-Jensen B. Wound care: a collaborative practice manual for health professionals. Baltimore (US): Lippincot, Willians and Wilkins; 2007. p. 197-212.

4. Waidman MAP, Rocha SC, Correa JL, Brischiliari A, Marcon SS. O cotidiano do indivíduo com ferida crônica e sua saúde mental. Texto Contexto Enferm. 2011 Out-Dez; 20(4):691-9.

5. Bardin L. Análise de conteúdo. Lisboa (PT): Edições 70; 2009. p.287-90.
6. Conselho Regional de Enfermagem (SC). Parecer $n^{\circ}$ 010/AT/2004, 19/03/2004: Desbridamento mecânico de feridas. Florianópolis. COREN-SC, 2004. [acesso 2011 Fev 17]. Disponível em: http:/ / www.coren-sc.org.br/

7. Conselho Regional de Enfermagem (DF). Parecer $n^{\circ}$ 004/2007, 23/04/2007: Possibilidade do enfermeiro indicar e/ou realizar desbridamento cirúrgico. Brasília. COREN-DF, 2007. [acesso 2011 Fev 25]. Disponível em: http:/ / www.coren-df.org.br

8. Conselho Regional de Enfermagem (SP). Parecer $\mathrm{N}^{\circ}$ 013/2009, 21/12/2009: Realização de desbridamento pelo enfermeiro. São Paulo. COREN-SP, 2009. [acesso 2011 Mar 09]. Disponível em: http://inter. coren-sp.gov.br/node/ 230

9. Conselho Regional de Enfermagem (PE). Parecer $n^{\circ}$ 016/2010, 07/07/2010: Solicitação de parecer quanto ao desbridamento de feridas por Profissionais de Enfermagem. Recife. COREN-PE, 2010. [acesso 2011 Mar 29]. Disponível em: http://www.corenpe.com.br

10. Conselho Regional de Enfermagem (MG). Deliberação n 65/2000, 22/05/2000: Competências dos profissionais de enfermagem na prevenção e tratamento das lesões cutâneas. Belo Horizonte. COREN-MG, 2000 [acesso 2011 Abr 13]. Disponível em: http:/ / www.corenmg.gov.br

11. Ferreira $\mathrm{ABH}$. Novo dicionário Aurélio da língua portuguesa. $5^{\text {a }}$ ed. São Paulo (SP): Positivo; 2010.

12. Cunha SS. Dicionário compacto do Direito. $9^{\mathrm{a}} \mathrm{ed}$. São Paulo (SP): Saraiva; 2010.

13. Mandelbaum SH, Di Santis EP, Mandelbaum MHSA. Cicatrização: conceitos atuais e recursos auxiliares - Parte I. An bras Dermatol. 2003 JulAgo;78(4):393-410.

14. Grossi MAF, Lehman LF, coordenadoras. Atualização em técnicas de curativos: uma abordagem multidisciplinar. Belo Horizonte (MG): The Continuing Education Network; 1996.

15. Cornell RS, Meyr AJ, Steinberg JS, Attinger CE. Debridement of the noninfected wound. J Am Podiatr Med Assoc. 2010 Sep; 100(5):353-9.

16. Declair V, Prazeres SJ. Desbridamento de feridas. In: Prazeres SJ, organizador. Tratamento de feridas: teoria e prática. Porto Alegre (RS): Moriá; 2009. p. 203-18.

17. Geovanini T, Oliveira Junior AG. Manual de curativos. $2^{a}$ ed. São Paulo (SP): Corpus; 2008. p. 64-5.

18. Ministério da Saúde (BR). Secretaria de Vigilância em Saúde. Manual de condutas para tratamento de úlceras em hanseníase e diabetes. $2^{\mathrm{a}}$ ed. Brasília (DF): MS; 2008. p. 42-50.

19. Cardinal M, Eisenbud D, Armstrong D, Zelen C, Driver V, Attinger C, et al. Serial surgical debridement: a retrospective study on clinical 
outcomes in chronic lower extremity wounds. Wound Repair Regen. 2009 May-Jun; 17(3):306-11.

20. Preece J. Sharp debridement: the need for training and education. Nurs times. 2008 Jun; 99(25):54-8.

21. Sinha SN. Wound debridement: doing and teaching. Primary Intention J. 2007 Nov; 15 (4):162-4.

22. Shannon R, Harris C, Harley C, Kozell K, Woo K, Alavi A et al. the importance of sharp debridement in foot ulcer care in the community:a cost-benefit evaluation. Wound Care. 2008 May; 5 Suppl. 1:51-2.

23. Giurini JM. Surgical treatment of ulcerated foot. In: Veves A, Giurini JM, LoGerfo FW (editors). The diabetic foot. $2^{\text {nd }}$ New Jersey: Humana Press; 2006. p. 335-62.

24. Williams A. The diabetic foot and its management. Br J Community Nurs. 2008 Apr; 22(4):22-8. 